\title{
Heterosis for Flowering Time and Agronomic Traits among Early Open-pollinated Sweet Corn Cultivars
}

\author{
T.E. Dickert and W.F. Tracy ${ }^{1}$ \\ Department of Agronomy, University of Wisconsin-Madison, WI 53706
}

\begin{abstract}
ADDITIONAL INDEX WORDS. Zea mays, maize, maturity, combining ability
ABSTRACT. Heterosis in corn (Zea mays L.) usually results in earlier flowering, larger plants, and increased yield. In extremely early sweet corn the effect of heterosis on flowering time may be reduced or eliminated due to developmental and physiological requirements for vegetative growth before the transition to reproductive phase. The objective of this study was to determine the level of heterosis and the combining ability for flowering time and other agronomic traits in a diallel cross of six very early open-pollinated sweet corn cultivars. The diallel was grown in 1995 and 1996 . Hybrids and parents averaged over hybrids differed for silk date, plant height, ear height, 10-ear weight, ear length, and 100-kernel weight but did not differ for row number and ear width. Heterosis for silk date was significant, but the difference between parents and hybrids was very small, 0.5 day. No hybrids were earlier than the earliest parent, and average midparent heterosis was $-0.8 \%$. In contrast midparent heterosis was significant and relatively high for 100-kernel weight $(10.0 \%)$, ear length $(12.9 \%)$, ear height $(8.6 \%)$, plant height $(\mathbf{9 . 0 \%})$, and 10-ear weight $(\mathbf{2 8 . 2 \%})$. The traits with low heterosis had very high general combining ability/specific combining ability ratios while these ratios were much smaller in traits with high heterosis. Heterosis for many of the traits, including 10-ear weight, was higher than published values. Conversely, heterosis for flowering time was small, compared to other traits in this study and to published values for silk date, indicating that this extremely early germplasm may be at or near the limit for flowering time under the photoperiod and temperatures typical of summer in Madison, Wis. $\left(43.05^{\circ} \mathrm{N}, 89.31^{\circ} \mathrm{W}\right)$.
\end{abstract}

Early maturity in sweet corn (Zea mays), especially for northern U.S. production areas is an important breeding objective. In northern areas, early maturing fresh market sweet corn usually commands the highest prices. Early maturing sweet corn, when planted early in the season, can escape certain diseases such as common rust (Puccinia sorghi) and maize dwarf mosaic virus and also the high temperatures of July and August (Alessi and Power, 1975; Tracy, 1999).

In sweet corn production, harvestable maturity is defined by grain moisture associated with optimal flavor, tenderness, and texture (Tracy, 1999). Optimal moisture at harvest in sul sweet corn is between $70 \%$ and $75 \%$ (Huelsen, 1954). The growing period between germination and harvest maturity can be divided into two growth phases, vegetative, from emergence to pollen shed; and reproductive, from silk emergence to maturity (Ritchie et al., 1997). In temperate sweet corn, the length of the vegetative phase (flowering time) has a greater role in determining maturity than does the length of the reproductive phase (Huelsen, 1954).

There is a relative lack of literature on the inheritance of flowering time in sweet corn, but there have been many studies in field corn. Early corn, for use as grain or silage is important in the United States. The United States leads in producing the greatest amount of early corn for grain with 24 million hectares (Troyer, 1994).

Wide variability in length of the preflowering period results in the most important basis of selection for early maturity (Dessureaux et al., 1948). Corn has a determinate growth pattern and the vegetative stage ends with the initiation of the terminal inflorescence (Kiesselbach, 1949). Flowering date is also associated strongly with plant height because internode formation ceases at floral initiation. Therefore, earlier flowering corns are usually shorter (Troyer, 1990; Troyer and Larkins, 1985). With selection for early

Received for publication 22 Oct 2001. Accepted for publication 8 May 2002. Contribution from the Wisconsin Agricultural Experiment Station. Research supported by the College of Agricultural and Life Sciences, Univ. of WisconsinMadison.

${ }^{1}$ To whom reprint requests should be addressed; wftracy@facstaff.wisc.edu. flowering, Troyer and Larkins (1985) found that plant height decreased $23 \mathrm{~mm} /$ cycle.

Selection for early pollen shed moved the mean of two early populations from 69.8 to $68.0 \mathrm{~d}$ and 69.9 to $68.1 \mathrm{~d}$ in three cycles of selection for a decrease of $0.6 \mathrm{~d} /$ cycle (Beil, 1975). This selection program for early pollen shed had no apparent effect on the level of genetic diversity in the population (Beil, 1975).

In a selection study for early flowering on 18 adapted $\mathrm{F}_{2}$ populations, Troyer (1986) reported a decrease of $0.6 \mathrm{~d} /$ cycle in flowering date, $0.6 \% /$ cycle in grain moisture, $2.4 \mathrm{~cm} /$ cycle in plant height, and $0.1 \mathrm{~d} /$ cycle silk delay, and a yield increase of 364 $\mathrm{kg} \cdot \mathrm{ha}^{-1}$ per cycle, with no effect on stalk breakage. In a similar experiment on adapted $\mathrm{F}_{2}$ populations, gain per cycle averaged a reduction of $1.2 \mathrm{~d}$ to flower, $1.0 \%$ grain moisture, $7.0 \mathrm{~cm}$ plant height, $0.1 \mathrm{~d}$ silk delay, and $238 \mathrm{~kg} \cdot \mathrm{ha}^{-1}$ yield, and an increase of 0.5 ear per 100 plants, and 3.7\% stalk breakage (Troyer, 1986). In a study on selection response to early flowering for four cycles in adapted synthetics, reduction in days to flowering averaged $0.8 \mathrm{~d} /$ cycle, with reductions of $10 \mathrm{~g} \cdot \mathrm{kg}^{-1}$ grain moisture, $4.0 \mathrm{~cm}$ plant height, $2.7 \mathrm{~cm}$ ear height, $0.2 \mathrm{~d}$ silk delay, and $0.15 \mathrm{Mg} \cdot \mathrm{ha}^{-1}(3 \%)$ yield, and an increase of $4 \%$ broken stalks (Troyer, 1990). The decrease in yield due to selection displayed close association with decrease in plant size, which probably reduced photosynthetic capacity (Troyer, 1990).

The rate of maturation in field corn results from complex interactions of genetic and environmental factors and is affected by the photoperiod response of corn (Troyer, 1994). Inheritance of flowering time in corn is controlled quantitatively. The genes involved act in an additive manner and heterosis complicates studying the inheritance of flowering time (Troyer, 1994). Most studies agree that more than two genes are responsible for the timing of silking and pollen shed with some evidence of partial to complete dominance and epistasis (Giesbrecht, 1960a, 1960b). On average, days to flower decreases by as much as $10 \%$ due to heterosis (Troyer, 1994). Vigor accelerates flowering time. Inbreeding decreases vigor and delays flowering time (Troyer, 1994).

Understanding heterotic responses among germplasm sources is useful in determining the best method for introgressing germplasm with desirable traits into populations that are agronomically and 
horticulturally acceptable (Widstrom et al., 1993). Heterosis in maize increases with increased genetic divergence of the parents but decreases when parents are extremely divergent (Moll et al., 1962, 1965).

At the University of Wisconsin-Madison we have collected a large number of open-pollinated sweet corn cultivars (Revilla and Tracy, 1995). Of these, we identified six early flowering cultivars. In Madison, the earliest of these, 'Yukon Chief', flowers $49 \mathrm{~d}$ after planting (DAP) and attains a height of only $72 \mathrm{~cm}$. This is roughly one week earlier than 'Sugar Buns', a very early commercial sweet corn hybrid we use as an early check in our hybrid trials. We wanted to determine if hybrids among these six very early cultivars would exhibit heterosis for earliness or are approaching a limit for earliness. The objective of this study was to determine the level of heterosis and the combining ability for flowering time and other agronomic traits among the six very early cultivars.

\section{Materials and Methods}

A diallel cross (Method I of Griffing, 1956) was made with six open-pollinated sweet corn cultivars in 1994. The cultivars were 'Yukon Chief', 'Golden Early Market', 'Dorinny', 'Early June', and 'Sweet Baby Blue' (Revilla and Tracy, 1995), and 'Golden Midget' from Garden City Seed Company, Victor, Montana. Cultivars were chosen due to their earliness based on evaluation of $\approx 50$ open-pollinated cultivars (Revilla and Tracy, 1995). For each cross, pollen from 25 plants from one cultivar was bulked. This pollen was used to pollinate 25 plants from the second cultivar. This was done twice so at least 50 plants from each cultivar were used to make each cross. The resulting 15 hybrids, 15 reciprocals, and 6 parents were entries in the diallel. On 30 May 1995 and 30 May 1996 seeds from each of the hybrids and parents were planted in a Plano silt loam (fine-silty, mixed, mesic Typic Argiudolls) soil at the West Madison Agricultural Research Station. The experimental design was a randomized complete block with four replications in each year.

To reduce interplot competition, plots were four rows with data collected on the center two rows. The rows were over-planted with 30 seeds per row and thinned to a stand of 15 plants per row both years. The rows were $3.5 \mathrm{~m}$ long with $76 \mathrm{~cm}$ between rows. The final population density was $\approx 44,500$ plants/ha. Weeds were controlled with $2.3 \mathrm{~L} \cdot \mathrm{ha}^{-1}$ cyanazine, $2.3 \mathrm{~L} \cdot \mathrm{ha}^{-1}$ alachlor, cultivation, and hand weeding.

The following traits were recorded before harvest: silk date defined as days after planting to $50 \%$ silking (DAP), plant height (from the soil to the ligule of the leaf subtending the tassel), and ear height (from the soil to the ligule of the leaf subtending the ear). Plant and ear heights of 10 plants per plot were measured. After all entries had completed dry matter accumulation (black layer formation), all ears from the center two rows were harvested and husked. From each plot, 10 representative ears were dried at $52{ }^{\circ} \mathrm{C}$ until constant weight. Numbers of rows per ear, ear length, ear diameter, 10-ear weight, and 100-kernel weight were recorded.

Analysis of variance was performed for each of the eight traits combined across years. Years and replications within years were considered random and all other effects were fixed. SAS was used for combined analysis of variance (SAS, Cary, N.C.). For each year, heterosis, combining ability, and mean comparisons for the parents across hybrids were computed using the diallel analysis of Burow and Coors (1994). Spearman rank correlation coefficients were calculated to determine whether significant year $\times$ combination effects were due to changes in magnitude or rank (Little and Hill, 1978).

\section{Results and Discussion}

All traits differed over years. Parents did not differ for ear width, but did so for all other traits. Genotypes, combinations (parents and all hybrid combinations), and hybrids differed for all traits. Reciprocals within hybrids differed for plant height, ear height, and 100kernel weight. The contrast, parents versus hybrids, was significant for silk date, plant height, ear height, 10-ear weight, ear length and 100 -kernel weight. Though there were significant year $\times$ combination effects, rank correlations ( silk date $r_{\mathrm{s}}=1.00$, 10-ear weight $r_{\mathrm{s}}=$ 0.73 , row number $r_{\mathrm{s}}=0.64,100$-kernel weight $r_{\mathrm{s}}=0.86, \mathrm{n}=36$ ) were high over the two years and the differences were due largely to changes in magnitude. Therefore, data averaged over years are reported.

In this study, DAP to midsilk (50\% silking) were used to determine midparent heterosis for flowering time. Mean silk date of parents averaged over hybrids was 53.1 DAP. For silk date averaged over hybrids, 'Yukon Chief' resulted in the earliest hybrids (51.4 DAP) and 'Golden Midget' the latest (54.4 DAP) (Table 1). The earliest parent per se was 'Yukon Chief' (48.8 DAP) and the latest parent was 'Golden Midget' (56.2DAP). 'Yukon Chief' $x$ 'Dorinny' was the earliest hybrid (48.5 DAP). The latest hybrid was 'Sweet Baby Blue' x 'Golden Midget' (55.6 DAP).

For silk date over all parents, average midparent heterosis equaled $-0.8 \%$. Negative heterosis indicates earlier flowering. This is smaller than heterosis observed for silk date $(-3.0 \%)$ by Revilla and Tracy (1997). Averaged over hybrids, the greatest midparent heterosis for silk date was $-1.7 \%$ for 'Early June' and $-1.0 \%$ for 'Sweet Baby Blue' (Table 1). 'Yukon Chief' averaged the least

Table 1. Mean silk date of 15 sweet corn population hybrids (above diagonal), six parent populations (on diagonal), six parent populations averaged over hybrids (left margin), percent heterosis (below diagonal), and average heterosis for each parent (bottom margin) from the Design 1 experiment grown in 2 years.

\begin{tabular}{|c|c|c|c|c|c|c|c|}
\hline \multirow{2}{*}{$\begin{array}{l}\text { Sweet corn } \\
\text { population }\end{array}$} & \multicolumn{7}{|c|}{ Sweet corn population (days after planting) } \\
\hline & $\mathrm{YC}^{\mathrm{z}}$ & GEM & DOR & EJ & SBB & GM & Mean \\
\hline $\mathrm{YC}$ & $48.8^{y}$ & 52.0 & 48.5 & 52.2 & 51.5 & 53.0 & $51.4^{\mathrm{x}}$ \\
\hline DOR & -3.6 & -0.8 & 51.9 & 53.0 & 51.9 & 53.7 & 52.0 \\
\hline EJ & 1.0 & -1.8 & -0.6 & 54.7 & 55.1 & 54.4 & 53.7 \\
\hline SBB & -1.0 & -0.9 & -3.1 & 0.2 & 55.2 & 55.6 & 53.7 \\
\hline
\end{tabular}

${ }^{\mathrm{z} Y C}=$ Yukon Chief, GEM = Golden Early Market, DOR = Dorinny, EJ = Early June, SBB = Sweet Baby Blue, GM = Golden Midget.

$\mathrm{y}_{\mathrm{LSD}_{(0.05)}}=1.0$ for comparisons among hybrid and parent mean silk dates.

$\mathrm{x}_{\mathrm{LSD}}^{(0.05)}=0.5$ for comparisons among parent mean silk dates averaged over hybrids. 
amount of heterosis for silk date $(-0.4 \%)$. Though there is a great deal of literature on midparent heterosis for yield, there is relatively little on traits such as silk date. In pearl millet, midparent heterosis for earliness was reported as large as $-10.8 \%$ (negative being indicative of earlier flowering) and as little as $13.7 \%$ (Chowdari et al., 1998). Castro et al. (1968) found that in genetically diverse races of maize there was $-1.6 \%$ average midparent heterosis for days to flower. Widstrom et al. (1993) reported $-2.7 \%$ heterosis for days to $50 \%$ pollen. In our experiment midparent heterosis for silk date was greatest in hybrids between 'Dorinny' $x$ 'Yukon Chief' and 'Sweet Baby Blue' $x$ 'Dorinny', $-3.6 \%$ and $-3.1 \%$ (Table 1). Hybrids 'Yukon Chief' x 'Early June' and 'Yukon Chief' x 'Golden Midget' exhibited the least heterosis $(1.0 \%)$.

Mean plant height among hybrids was $92.4 \mathrm{~cm}$. When averaged over hybrids 'Golden Early Market' $(101.1 \mathrm{~cm})$ resulted in the tallest hybrids, and 'Yukon Chief' the shortest $(85.1 \mathrm{~cm})$ (Table 2). For parents, the tallest was 'Golden Early Market' $(104.2 \mathrm{~cm})$, and the shortest was 'Sweet Baby Blue' $(62.0 \mathrm{~cm})$. Among hybrids 'Golden Early Market' X 'Early June' plants were tallest $(109.6 \mathrm{~cm})$, and 'Yukon Chief' X 'Sweet Baby Blue' plants were shortest $(76.6 \mathrm{~cm})$.

Average midparent heterosis for plant height was $9.0 \%$. This is comparable to what Revilla and Tracy (1997) found for average heterosis for plant height (7.9\%). 'Sweet Baby Blue' had the greatest average heterosis (16.0\%), and 'Dorinny' had the lowest (6.5\%) (Table 2). The hybrids 'Golden Midget' $x$ 'Sweet Baby Blue' and 'Sweet Baby Blue' $x$ 'Early June' had the greatest midparent heterosis with $17.9 \%$ and $17.8 \%$, respectively. 'Early June' $x$ 'Dorinny' had the least heterosis for plant height (1.0\%). Only $4.4 \%$ midparent heterosis for plant height was observed among insectresistant maize populations, (Widstrom et al., 1993). Over six cycles of selection between sweet corn $x$ tropical corn, midparent heterosis for plant height ranged from $14.3 \%$ to $21.8 \%$ (Rubino and Davis, 1990), and from inbred crosses $39.4 \%$ was observed (Zanoni and Dudley, 1989).

Mean 10-ear weight for hybrids was $449.7 \mathrm{~g}$. Averaged over hybrids 'Golden Early Market' resulted in the heaviest 10-ear weight (532.1 g), and 'Golden Midget' had the lightest (413.4 g) (Table 3). Among parents, 'Golden Early Market' had the heaviest 10-ear weight (578.9 g), and 'Sweet Baby Blue' had the lightest (234.5 g). The highest yielding hybrid was 'Golden Early Market' X 'Early June' (561.1 g). The lowest yielding hybrid was 'Yukon Chief' $x$ 'Golden Midget' (373.8 g).

Average midparent heterosis for 10 -ear weight was $28.2 \%$ (Table 3). While not a direct measurement of grain yield, this value for 10-ear weight exceeds those reported for grain yield in openpollinated field corn cultivar diallels. For example, average midparent heterosis for yield in temperate synthetic cultivars equaled $11 \%$ (Hallauer and Eberhart, 1966), 14\% for semi-exotic varieties (Eberhart, 1971), 20\% for Caribbean populations (Moll etal., 1962), $20.1 \%$ among Spanish cultivars (Ordas, 1991), 22.5\% in insect resistant corn populations (Widstrom et al., 1993), and $24.8 \%$ in genetically diverse races (Castro et al., 1968). In a similar study on heterotic patterns of full season open-pollinated sweet corn cultivars, average midparent heterosis for yield was $29.2 \%$ (Revilla and Tracy, 1997). Revilla and Tracy (1997) suggested that the sweet corn cultivars might have been more inbred than the field corn

Table 2. Mean plant heights of 15 sweet corn population hybrids (above diagonal), six parent populations (on diagonal), six parent populations averaged over hybrids (left margin), percent heterosis (below diagonal), and average heterosis for each parent (bottom margin) from the Design 1 experiment grown in 2 years.

\begin{tabular}{|c|c|c|c|c|c|c|c|}
\hline \multirow{2}{*}{$\begin{array}{l}\text { Sweet corn } \\
\text { population }\end{array}$} & \multicolumn{7}{|c|}{ Sweet corn population $(\mathrm{cm})$} \\
\hline & $\mathrm{YC}^{\mathrm{z}}$ & GEM & DOR & EJ & SBB & GM & Mean \\
\hline $\mathrm{YC}$ & $72.6^{\mathrm{y}}$ & 93.4 & 85.2 & 84.4 & 76.6 & 86.1 & $85.1^{\mathrm{x}}$ \\
\hline DOR & 5.8 & 6.1 & 88.5 & 92.1 & 86.4 & 93.2 & 91.8 \\
\hline EJ & 1.3 & 10.6 & 1.0 & 94.0 & 91.9 & 95.7 & 94.7 \\
\hline SBB & 13.8 & 15.8 & 14.8 & 17.8 & 62.0 & 89.0 & 88.0 \\
\hline
\end{tabular}

${ }^{\mathrm{Z} Y C}=$ Yukon Chief, GEM = Golden Early Market, DOR = Dorinny, EJ = Early June, SBB = Sweet Baby Blue, GM = Golden Midget.

$\mathrm{y}_{\mathrm{LSD}_{(0.05)}}=5.2$ for comparisons among hybrid and parent mean plant heights.

$\mathrm{x}_{\mathrm{LSD}}(0.05)=2.3$ for comparisons among parent mean plant heights averaged over hybrids.

Table 3. Mean 10-ear weights of 15 sweet corn population hybrids (above diagonal), six parent populations per se (on diagonal), six parent populations averaged over hybrids (left margin), percent heterosis (below diagonal), and average heterosis for each parent (bottom margin) from the Design 1 experiment grown in 2 years.

\begin{tabular}{|c|c|c|c|c|c|c|c|}
\hline \multirow{2}{*}{$\begin{array}{l}\text { Sweet corn } \\
\text { population }\end{array}$} & \multicolumn{7}{|c|}{ Sweet corn population (g) } \\
\hline & $\mathrm{YC}^{\mathrm{z}}$ & GEM & DOR & EJ & SBB & GM & Mean \\
\hline $\mathrm{YC}$ & $279.1^{y}$ & 521.1 & 410.8 & 405.6 & 381.9 & 373.8 & $418.6^{x}$ \\
\hline DOR & 22.1 & 15.2 & 393.6 & 483.0 & 422.5 & 399.1 & 455.1 \\
\hline EJ & 25.0 & 18.7 & 27.1 & 366.1 & 414.8 & 382.0 & 449.3 \\
\hline SBB & 48.7 & 27.4 & 34.4 & 38.1 & 234.5 & 412.1 & 429.9 \\
\hline
\end{tabular}

$\overline{\mathrm{z} Y C}=$ Yukon Chief, GEM = Golden Early Market, DOR = Dorinny, EJ = Early June, SBB = Sweet Baby Blue, GM = Golden Midget.

$\mathrm{y}_{\mathrm{LSD}_{(0.05)}}=51.6$ for comparisons among hybrid and parent mean 10-ear weights.

${ }^{\mathrm{x}_{\mathrm{LSD}}}(0.05)=23.1$ for comparisons among parent mean 10-ear weights averaged over hybrids. 
Table 4. Mean trait values for parent and hybrid means averaged over six parents and averaged over 30 hybrids grown in 2 years.

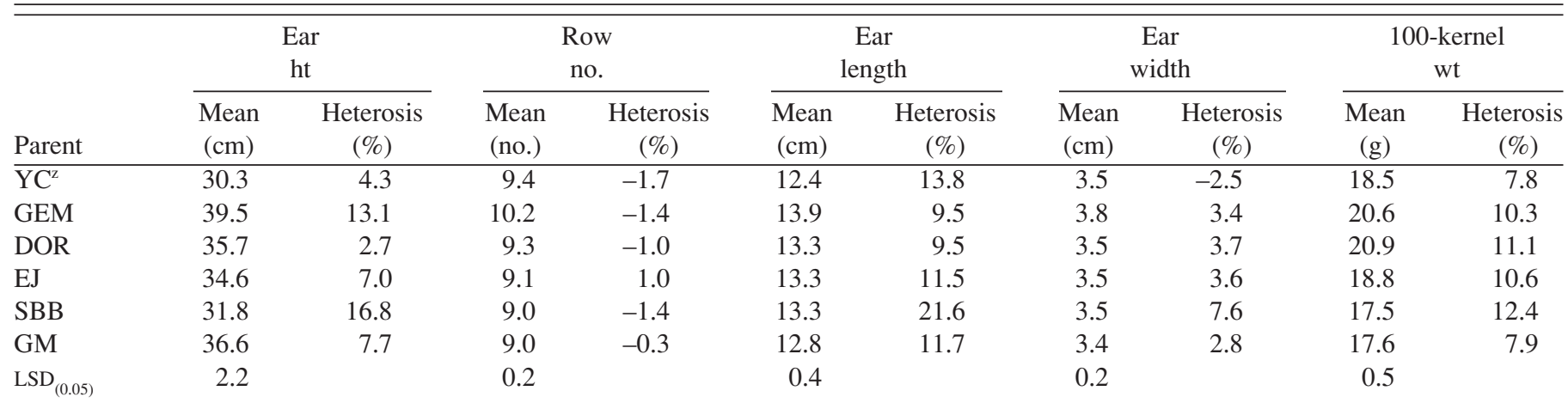

${ }^{\mathrm{z} Y C}=$ Yukon Chief, GEM = Golden Early Market, DOR = Dorinny, EJ = Early June, SBB = Sweet Baby Blue, GM = Golden Midget.

cultivars of other studies. In tropical maize germplasm, the greatest average midparent heterosis for yield reported was $17.2 \%, 20.2 \%$ in transition and midaltitude maize germplasm (Vasal et al., 1992b), and $23.7 \%$ in subtropical maize germplasm.

'Sweet Baby Blue' had the greatest average heterosis for 10-ear weight (41.6\%) (Table 3), and 'Golden Early Market' had the smallest average midparent heterosis (19.8\%). 'Golden Midget' X 'Sweet Baby Blue' and 'Sweet Baby Blue' $x$ 'Yukon Chief' had the greatest heterosis for 10 -ear weight $(59.5 \%$ and $48.7 \%$, respectively). These values are much greater than many of the field corn values reported. 'Golden Early Market' had the lowest heterosis when crossed to 'Dorinny' and 'Golden Midget' at $15.2 \%$ and $16.1 \%$, respectively.

Mean ear height among hybrids was $34.8 \mathrm{~cm}$. Averaged over hybrids 'Golden Early Market' had the greatest ear height $(39.5 \mathrm{~cm})$, and 'Yukon Chief' the lowest $(30.3 \mathrm{~cm})$ (Table 4). Average midparent heterosis for ear height was $8.6 \%$. Among insect-resistant populations, midparent heterosis for ear height was 3.7\% (Widstrom et al., 1993), 5\% in semi-exotic varieties (Eberhart, 1971), $11.5 \%$ to $23.9 \%$ among six cycles of selection in sweet corn $x$ tropical maize (Rubino and Davis, 1990), and 49.1\% among inbreds (Zanoni and Dudley, 1989). 'Sweet Baby Blue' had the greatest average midparent heterosis at $16.8 \%$ (Table 4). 'Dorinny' had the smallest midparent heterosis for ear height $(2.7 \%)$.

Mean row number over hybrids was 9.3 rows. The greatest row number averaged over hybrids was in 'Golden Early Market' hybrids (10.2 rows) (Table 4). The lowest was in 'Golden Midget' and 'Sweet Baby Blue' hybrids (9.0 rows). Average midparent heterosis for row number equaled $-0.8 \%$. 'Early June' had the greatest average midparent heterosis at $1.0 \%$ and 'Yukon Chief' had the smallest $(-1.7 \%)$. Over six cycles of selection in sweet corn $x$ tropical maize testcross, mean midparent heterosis ranged from $-0.6 \%$ to $3.3 \%$ (Rubino and Davis, 1990), comparable to values in our study.

Mean ear length for hybrids was $13.1 \mathrm{~cm}$. Averaged over hybrids, 'Golden Early Market' resulted in the longest ears (13.9 $\mathrm{cm}$ ) and 'Yukon Chief' the shortest $(12.4 \mathrm{~cm})$ (Table 4). Average midparent heterosis for ear length was $12.9 \%$. 'Sweet Baby Blue' had the greatest average midparent heterosis (21.6\%) (Table 4). 'Golden Early Market' and 'Dorinny' had the smallest midparent heterosis for ear length (9.5\%). Over six cycles of selection in a sweet corn $x$ tropical maize study, mean midparent heterosis for ear length ranged from $14.4 \%$ to $44.7 \%$ (Rubino and Davis, 1990), and in pearl millet, it ranged form $-10.4 \%$ to $46.8 \%$ (Chowdari et al., 1998).

Mean ear width for hybrids was $3.5 \mathrm{~cm}$. When averaged over hybrids 'Golden Early Market' had the widest ears $(3.8 \mathrm{~cm})$ (Table 4), and 'Golden Midget' the narrowest ears $(3.4 \mathrm{~cm})$. Average midparent heterosis for ear width was 3.1\%. 'Sweet Baby Blue' had the greatest average heterosis (7.6\%), and 'Yukon Chief' had the least $(-2.5 \%)$ (Table 4). In pearl millet, midparent heterosis for ear width ranged from $-3.5 \%$ to $29.5 \%$ (Chowdari et al., 1998).

Mean 100-kernel weight for hybrids was $19.0 \mathrm{~g}$. When averaged overhybrids, 'Dorinny' had the heaviest kernels (20.9 g) and 'Sweet

Table 5. Mean squares for general combining ability (GCA) and specific combining ability (SCA) and ratios of general combining ability to specific combining ability (GCA/SCA) for silk date, plant height, ear height, 10 ear weight, row number, ear length, ear width and 100 kernel weight from a six parent diallel grown in 2 years.

\begin{tabular}{|c|c|c|c|c|c|c|c|c|}
\hline Parent & $\begin{array}{l}\text { Silk } \\
\text { date }\end{array}$ & $\begin{array}{c}\text { Plant } \\
\text { ht }\end{array}$ & $\begin{array}{c}\text { Ear } \\
\text { ht }\end{array}$ & $\begin{array}{c}\text { 10-ear } \\
\text { wt }\end{array}$ & $\begin{array}{c}\text { Row } \\
\text { no. }\end{array}$ & $\begin{array}{l}\text { Ear } \\
\text { length }\end{array}$ & $\begin{array}{c}\text { Ear } \\
\text { width }\end{array}$ & $\begin{array}{c}\text { 100-kernel } \\
\text { wt }\end{array}$ \\
\hline$\overline{\mathrm{GCA}}$ & $188.5280^{* *}$ & $4695.0200^{* * *}$ & $1096.3500^{* * *}$ & $320442.4100^{* *}$ & $25.9796^{* *}$ & $48.8502^{* * *}$ & $2.8079^{* * *}$ & $26038.9600^{* * *}$ \\
\hline SCA & $4.5660^{* *}$ & $285.8300^{* * *}$ & $63.1300^{* * *}$ & $27478.4800^{* * *}$ & $0.7082 * *$ & $8.4880^{* * *}$ & $0.2322^{*}$ & $954.7400^{* * *}$ \\
\hline
\end{tabular}

${ }^{*, * *}$ Significant at $P=0.05$ or 0.01 , respectively.

Table 6. Mean trait values for parent and hybrid means averaged over six parents and averaged over 30 hybrids grown in 2 years.

\begin{tabular}{|c|c|c|c|c|c|c|c|c|}
\hline $\begin{array}{l}\text { Parent or } \\
\text { hybrid }\end{array}$ & $\begin{array}{c}\text { Silk } \\
\text { date } \\
(\mathrm{DAP})^{\mathrm{z}}\end{array}$ & $\begin{array}{l}\text { Plant } \\
\text { ht } \\
(\mathrm{cm})\end{array}$ & $\begin{array}{c}\text { Ear } \\
\text { ht } \\
(\mathrm{cm})\end{array}$ & $\begin{array}{c}\text { 10-ear } \\
\text { wt } \\
(\mathrm{g})\end{array}$ & $\begin{array}{l}\text { Row } \\
\text { (no.) }\end{array}$ & $\begin{array}{c}\text { Ear } \\
\text { length } \\
(\mathrm{cm})\end{array}$ & $\begin{array}{c}\text { Ear } \\
\text { width } \\
(\mathrm{cm})\end{array}$ & $\begin{array}{c}\text { 100-kernel } \\
\text { wt } \\
(\mathrm{g})\end{array}$ \\
\hline Parents & $53.6^{* * *}$ & $85.1^{* * *}$ & $31.8^{* * *}$ & $357.4^{* *}$ & $9.43^{\mathrm{NS}}$ & $11.7^{* * *}$ & $3.4^{\mathrm{NS}}$ & $17.2^{* * *}$ \\
\hline Hybrids & 53.1 & 93.4 & 35.6 & 448.0 & 9.39 & 13.1 & 3.5 & 18.9 \\
\hline
\end{tabular}

${ }^{\mathrm{z}} \mathrm{DAP}=$ days after planting.

Ns,** Nonsignificant or significant at $P=0.01$ for means within columns. 
Baby Blue' had the lightest (17.5 g) (Table 4). Average midparent heterosis for 100-kernel weight was 10.0\%. 'Sweet Baby Blue' had the greatest average midparent heterosis $(12.4 \%)$, and 'Yukon Chief' had the smallest (7.8\%)(Table 4).

Among parents, 'Golden Early Market' had the largest means for most of the traits. 'Golden Early Market' produced the greatest means averaged over hybrids for six of the eight traits analyzed. Also for six of the eight traits this cultivar exhibited the greatest means among parents. For seven of eight traits, the hybrid that exhibited the greatest means among hybrids included 'Golden Early Market' as a parent. The 10-ear weight of 'Golden Early Market' exceeded the next closest parent by $185 \mathrm{~g}$. 'Golden Early Market' performed well per se, and in hybrids but exhibited low heterosis because parent means were high. In contrast, 'Golden Midget' performed poorly. For four of the eight traits 'Golden Midget' had the smallest means averaged over hybrids. 'Sweet Baby Blue' exhibited the lowest means for six of the eight traits analyzed.

These six populations are maintained as open-pollinated varieties, however 'Sweet Baby Blue' may be more inbred than the other populations. 'Sweet Baby Blue' had small means for plant height, ear height, 10-ear weight, ear width and 100-kernel weight but had the largest midparent heterosis for plant height, ear height, 10-ear weight, ear length, ear width and 100-kernel weight. Inbreeding would explain the high heterosis displayed in 'Sweet Baby Blue' hybrids and the low per se performance.

General combining ability (GCA) was significant for all eight traits (Table 5). This corresponds to other experiments (Widstrom et al., 1993; Vasal, 1992a, 1992b, 1993) where GCA effects for corn cultivars are often significant in breeding experiments. Specific combining ability (SCA) was also significant for all eight traits (Table 5). This is in contrast to the research done on open-pollinated corn cultivars where SCA is rarely of great importance (Vasal et al., 1992a, 1992b, 1993; Widstrom et al., 1993). While SCA was significant for all traits, the GCA mean squares were $\approx 30$ to 40 times the SCA mean squares for silk date, row number and 100-kernel weight indicating that the SCA is relatively unimportant for these traits (Table 5).

There were small significant differences for silk dates between the parents and the hybrids (Table 6). Over all hybrids in this study we observed heterosis for silk date. Average silk date for hybrids (53.1 DAP) was earlier than average silk date for parents (53.6 DAP). However no hybrids were earlier than the earliest parent. Compared to the other traits with significant differences between parents and hybrids, the difference for silk date between the parental and hybrid means and heterosis were very small. There was no significant difference between parents and hybrids for row number and ear width. There were significant differences between hybrids and parents for plant height, ear height, 10-ear weight, ear length, and 100-kernel weight along with significant heterosis for these traits.

While heterosis for silk date was significant, the magnitude was smaller than observed in other studies and for the other heterotic traits in this study such as 10-ear weight and plant height. None of the hybrids were earlier than 'Yukon Chief' indicating that 'Yukon Chief' may be near the limit for earliness imposed by developmental or physiological constraints.

\section{Literature Cited}

Alessi, J. and J.F. Power. 1975. Response of an early-maturing corn hybrid to planting date and population in the northern plains. Agron. J. 67:762765.

Beil, G.M. 1975. Selection and development of inbred material for use in early maturing corn hybrids, p. 131-149. In: Proc. $30^{\text {th }}$ Corn and Sorghum Res. Conf. Chicago, Ill. 9-11 Dec. Amer. Seed Trade Assn., Wash., D.C. Burow, M.D. and J.G. Coors. 1994. Diallel: A microcomputer program for the simulation and analysis of diallel crosses. Agron. J. 86:154-158.

Castro, M.G., C.O. Gardner, and J.H. Lonnquist. 1968. Cumulative gene effects and the nature of heterosis in maize crosses involving genetically diverse races. Crop Sci. 8:97-101.

Chowdari, K.V., S.R. Venkatachalam, A.P. Davierwala, V.S. Gupta, P.K. Ranjekar, and O.P. Govila. 1998. Hybrid performance and genetic distance as revealed by the (GATA) ${ }_{4}$ microsatellite and RAPD markers in pearl millet. Theor. Appl. Genet. 97:163-169.

Dessureaux, L., N.P. Neal, and R.A. Brink. 1948. Maturation in corn. J. Amer. Soc. Agron. 40:733-745.

Eberhart, S.A. 1971. Regional maize diallels with US and semi-exotic varieties. Crop Sci. 11:911-914.

Giesbrecht, J. 1960a. The inheritance of maturity in maize. Can. J.Plant Sci. 40:490-499.

Giesbrecht, J. 1960b. The inheritance of time of silking and pollen shedding in maize. J. Genet. Cytol. 1:329-338.

Griffing, B. 1956. Concept of general and specific combining ability in relation to diallel crossing systems. Austral. J. Biol. Sci. 9:463-493.

Hallauer, A.R. and S.A. Eberhart. 1966. Evaluation of varieties of maize for yield. Crop Sci. 6:423-427.

Huelsen, W.A. 1954. Sweet corn. Interscience Publ. New York.

Kiesselbach, T.A. 1949. The structure and reproduction of corn. Neb. Agr. Exp. Sta. Bul. 161.

Little, T.M. and F.J.Hills. 1978. Agricultural experimentation. Wiley, New York.

Moll, R.H., W.S. Salhuana, and H.F. Robinson. 1962. Heterosis and genetic diversity in variety crosses of maize. Crop Sci. 2:197-198.

Moll, R.H., J.H. Lonnquist, J. Velez Fortuno, and E.C. Johnson. 1965. The relationship of heterosis and genetic divergence in maize. Genetics 52:139-144.

Ordas, A. 1991. Heterosis in crosses between American and Spanish populations of maize. Crop. Sci. 31:931-935.

Revilla, P. and W.F. Tracy. 1995. Morphological characterization and classification of open-pollinated sweet corn cultivars. Crop Sci. 120(1):112-118.

Revilla, P. and W.F. Tracy. 1997. Heterotic patterns among open-pollinated sweet corn cultivars. J. Amer. Soc. Hort. Sci. 122:319-324.

Ritchie, S.W., J.J. Hanway, and G.O. Benson. 1997. How a corn plant develops. Iowa State Univ. Coop. Ext. Serv. Spec. Rpt. 48.

Rubino, D.B. and D.W. Davis. 1990. Response of a sweet corn x tropical maize composite to mass selection for temperate-zone adaptation. J. Amer. Soc. Hort. Sci. 115:848-853.

Tracy, W.F. 1999. Sweet corn, p. 147-187. In: A.R. Hallauer (ed.). Specialty corns. CRC, Boca Raton, Fla.

Troyer, A.F. 1986. Selection for early flowering in corn: 18 adapted $\mathrm{F}_{2}$ populations. Crop Sci. 26:283-285.

Troyer, A.F. 1990. Selection for early flowering in corn: Three adapted synthetics. Crop Sci. 30:896-900.

Troyer, A.F. 1994. Breeding early corn, p. 341-396. In: A.R. Hallauer(ed.). Specialty corns. CRC, Boca Raton, Fla.

Troyer, A.F. and J.R. Larkins. 1985. Selection for early flowering in corn: 10 late synthetics. Crop Sci. 25:695-697.

Vasal, S.K., G. Srinivasan, J. Crossa, and D.L. Beck. 1992a. Heterosis and combining ability of CIMMYT's subtropical and temperate early-maturity maize germplasm. Crop Sci. 32:884-890.

Vasal, S.K., G. Srinivasan, F. Gonzalez C., G.C. Han, S. Pandey, D.L. Beck, and J. Crossa. 1992b. Heterosis and combining ability of CIMMYT's tropical X subtropical maize germplasm. Crop Sci. 32:1483-1489.

Vasal, S.K., G. Srinivasan, F. Gonzalez C., D.L. Beck, and J. Crossa. 1993. Heterosis and combining ability of CIMMYT's quality protein maize germplasm: II. Subtropical. Crop Sci. 33:51-57.

Widstrom, N.W., K. Bondari, and W.W. McMillian. 1993. Heterosis among insect-resistant maize populations. Crop Sci. 33:989-994.

Zanoni, U. and J.W. Dudley. 1989. Comparison of different methods of identifying inbreds useful for improving elite maize hybrids. Crop Sci. 29:577-582. 